\title{
Methylorosula polaris gen. nov., sp. nov., an aerobic, facultatively methylotrophic psychrotolerant bacterium from tundra wetland soil
}

Correspondence

Oleg R. Kotsyurbenko olk@helmholtz-hzi.de

\author{
Julia Ju. Berestovskaya, ${ }^{1}$ Oleg R. Kotsyurbenko, ${ }^{2}$ Tatyana P. Tourova, ${ }^{1}$ \\ Tatyana V. Kolganova, ${ }^{1}$ Nina V. Doronina, ${ }^{3}$ Peter N. Golyshin ${ }^{4}$ \\ and Lina $\mathrm{V}$. Vasilyeva ${ }^{1}$
}

${ }^{1}$ S. N. Winogradsky Institute of Microbiology, Russian Academy of Sciences, Prospect 60-let Octyabrya 7/2, Moscow 117312, Russia

${ }^{2}$ Technical University Braunschweig, Spielmannstrasse 7, Braunschweig, Germany

${ }^{3}$ G. K. Skryabin Institute of Biochemistry and Physiology of Microorganisms,

Russian Academy of Sciences, Pushchino, Russia

${ }^{4}$ School of Biological Sciences, Bangor University, Bangor LL57 2UW, Gwynedd, Wales, UK
Aerobic methylotrophic bacteria using one-carbon compounds, such as methane, methanol and methylated amines, are widespread in natural environments, being found in a variety of aquatic and terrestrial habitats (Anthony, 1982; Bowman et al., 1997; Sorokin et al., 2007). Many of the known strains of methylotrophic bacteria are obligately methylotrophic and use compounds containing no carboncarbon bonds (Lidstrom, 2006; Bowman et al., 1997; Bodrossy et al., 1997). However, a variety of organisms are known that can grow facultatively either on multicarbon compounds or on one carbon compounds (Doronina et al., 1998; Lidstrom, 2006; Dedysh et al., 2005a). Traditionally, the major function of aerobic methylotrophs (methanotrophs)

The GenBank/EMBL/DDBJ accession numbers for the 16S rRNA gene sequences of strains $\mathrm{V}-022^{\top}, \mathrm{Ch}-022$ and $\mathrm{Yu}-022$ are EU586035EU586037. The accession numbers for the $m x a F$ sequences of strains $\mathrm{V}-022^{\top}$ and $\mathrm{Yu}-022$ are EU586038 and EU586039, respectively. was believed to be that they form the principal biological sink for methane in the global methane cycle (Senum \& Gaffney, 1985). Recently it has been revealed that these bacteria thrive in a strong association with plants, which are a methanol emission source of global importance; plant-borne methanol makes up to $40-46 \%$ of the total volatile carbon in the atmosphere (MacDonald \& Fall, 1993). A possible explanation of such plant-bacterial associations is the participation of the latter in the 'methanol cycle' (Trotsenko et al., 2001). Methylotrophic bacteria have also been observed in hypersaline lakes where the total flux of methylated compounds is enhanced by their formation as degradation products from osmolytes (Sorokin et al., 2007). Aerobic methylotrophs could also form associations with methanotrophic bacteria and utilize the products of methane oxidation as their source of carbon and energy (Trotsenko \& Khmelenina, 2002). The present study describes three novel strains that are psychrotolerant, moderately acidophilic and facultatively 
methylotrophic bacteria that were isolated from methaneoxidizing communities of soil from the polar tundra of the Vorkuta region and of the Chukotka and Yugorsky Peninsulas of Russia.

Strains were isolated from acidophilic, methanotrophic enrichments obtained from Sphagnum peat of three tundra wetland sites of Northern Russia (Berestovskaya et al., 2002). Cell suspensions of these enrichments were spread onto medium 2A (Berestovskaya et al., 2002) agar plates, containing $2 \%(\mathrm{w} / \mathrm{v})$ agar (Difco). The medium was amended with $0.5 \%$ methanol as the sole carbon source and both amended and normal plates were placed into glass jars in which the atmosphere was adjusted to a $30: 70$ methane/air ratio. The plates were incubated at $10{ }^{\circ} \mathrm{C}$. As colonies became visible, they were successively restreaked onto fresh plates with the same solid medium until a culture with uniform colonies was obtained. The isolates from Vorkuta and the Chukotka and Yugorsky Peninsulas were designated, correspondingly, V- $022^{\mathrm{T}}$, Ch-022 and $\mathrm{Yu}-$ 022. The same medium (in both liquid and solid forms) was used for further physiological examination of the methylotrophs obtained.

Cell morphology and cell life cycle, as well as culture purity, were examined by using phase-contrast and electron microscopy. In the latter case, the samples were stained with $1 \%(\mathrm{w} / \mathrm{v})$ uranyl acetate. The procedure for the preparation of the ultrathin sections used in this work has been described elsewhere (Vasilyeva et al., 2006). The samples were examined with a JEM-100C transmission electron microscope.

Growth of isolates in liquid medium was monitored by spectrophotometry by measuring the turbidity at $600 \mathrm{~nm}$ for 2 weeks, with methanol as the sole growth substrate. Growth was examined with various temperatures $\left(4-38{ }^{\circ} \mathrm{C}\right), \mathrm{pH}$ values (4.0-8.0) and $\mathrm{NaCl}$ concentrations [0.01-2.50\% $(\mathrm{w} / \mathrm{v})]$. Variations in the $\mathrm{pH}$ level were achieved by mixing $0.05 \mathrm{M}$ solutions of $\mathrm{Na}_{2} \mathrm{HPO}_{4}$ and $\mathrm{KH}_{2} \mathrm{PO}_{4}$ to create media with the same ionic strength. To determine the range of potential growth substrates for strains $\mathrm{V}-022^{\mathrm{T}}, \mathrm{Ch}-022$ and $\mathrm{Yu}-022$, the following carbon sources, at a concentration of $0.5 \%(\mathrm{w} / \mathrm{v})$, were tested in liquid medium $2 \mathrm{~A}$ : methane, methanol, mono-, di-, and trimethylamines; the monosaccharides D-ribose, D-arabinose, D-xylose, lyxose, D-glucose, rhamnose, D-fructose, D-mannose and D-galactose; the disaccharides maltose, lactose, sucrose and trehalose; the trisaccharide raffinose; the polysaccharides starch and dextrin, sugar alcohols, glycerol, dulcitol, D-sorbitol, Dmannitol and inosine; the alcohols ethanol and butanol; the amino acids asparagine, L-glutamate, L-arginine, L-proline, isoleucine, phenylalanine, cysteine, serine, histidine, and methionine; the sodium salts of the organic acids pyruvate, lactate, succinate, malate, formate, acetate, propionate and butyrate; and yeast extract, Casamino acids and pectin. Autotrophic growth with hydrogen as the electron donor was studied at the optimal $\mathrm{pH}$ and temperature using $500 \mathrm{ml}$ serum bottles with $100 \mathrm{ml}$ medium under an atmosphere containing $20 \% \mathrm{CO}_{2}, 30 \%$ air and $50 \% \mathrm{H}_{2}$. Growth was examined after 14 days of incubation.

For fatty acid analysis, cells were grown on liquid medium $2 \mathrm{~A}$ with methanol and harvested in the late exponential growth phase. The analysis was performed by the DSMZ (Deutsche Sammlung von Mikroorganismen und Zellkulturen, Braunschweig, Germany).

In order to establish the routes of primary $\mathrm{C}_{1}$ metabolism in strain $\mathrm{V}-022^{\mathrm{T}}$, enzyme activities were determined in extracts of cell growth on methylamine. For the preparation of cell-free extracts, the biomass was harvested from cells at the exponential growth phase and washed twice with distilled $\mathrm{H}_{2} \mathrm{O}$. Concentrated cell suspensions prepared with $50 \mathrm{mM}$ Tris/HCl buffer $\mathrm{pH} 7.0$ were disrupted $(6 \times 1 \mathrm{~min})$ in an ultrasonic disintegrator (model $150 \mathrm{~W}$; MSE) at $4{ }^{\circ} \mathrm{C}$. The supernatant obtained by centrifugation of the cell homogenate at $30000 \mathrm{~g}$ for $1 \mathrm{~h}$ was used as a cell-free extract.

In order to measure the activities of methylamine dehydrogenase EC 1.4.99.3 (Eady \& Large, 1968), formaldehyde dehydrogenase (NAD/GSH-linked) EC 1.2.1.1, formate dehydrogenase EC 1.2.1.2, hydroxypyruvate reductase EC 1.1.1.25, 3-hexulosephosphatesynthase and ribulosebisphosphate carboxylase EC 4.1.1.39 (Loginova \& Trotsenko, 1979), enzyme assays were performed at $30{ }^{\circ} \mathrm{C}$ in cell-free extracts, according to the methods given in the papers cited above.

Spectrophotometric assays were performed with a Specord UV VIS machine and radioactivity was counted in a liquid scintillation spectrometer (SL-30; Intertechnique).

Enzyme activities were expressed as nmol of substrate transformed or of the product formed in $1 \mathrm{~min}$ per mg of protein. Protein concentration was determined by the method of Lowry (Lowry et al., 1951) using BSA as a reference.

The isolation of DNA, subsequent determination of the $\mathrm{G}+\mathrm{C}$ content and DNA-DNA hybridization experiments were performed according to the methods of Marmur (1961) and De Ley et al. (1970). The nearly complete $16 \mathrm{~S}$ rRNA gene was obtained using general bacterial primers $11 \mathrm{~F}-1492 \mathrm{R}$ according to standard protocols. The amplification of $m x a F$, the gene coding for methanol dehydrogenase, was performed with primer sets developed by McDonald \& Murrell (1997) and Dedysh et al. (2005b) according to the corresponding protocols. The amplification of $p m o A$ and $p m o F$ genes, encoding different forms of particulate methane monooxygenase, was performed with the primer set pmoA f189-pmoA r682 developed by Holmes et al. (1995) and a modified set with pmoF: 5'-GCGGATTCGGIGACTGGGACTTCTGG and pmoR: 5'-GCGAATTCGAASGCIGAGAAGAASGC. The content of the PCR mixture was the same as described above. The following program was applied: the initial cycle at $94{ }^{\circ} \mathrm{C}$ for $3 \mathrm{~min}$, $55{ }^{\circ} \mathrm{C}$ for $30 \mathrm{~s}$ and $72{ }^{\circ} \mathrm{C}$ for $30 \mathrm{~s}$ was followed by 35 cycles $\left(94{ }^{\circ} \mathrm{C}\right.$ for $30 \mathrm{~s}, 55{ }^{\circ} \mathrm{C}$ for $30 \mathrm{~s}$ and $72{ }^{\circ} \mathrm{C}$ for $30 \mathrm{~s}$ ) and a final 
extension step at $72{ }^{\circ} \mathrm{C}$ for $7 \mathrm{~min}$. The amplification of $m m o C$ and $m m o X$, genes coding for soluble methane monooxygenase subunits, was performed with the primer set $m m o C$ f542-mmoC $\mathrm{r} 986$ developed for $m m o \mathrm{C}$ genes by McDonald et al. (1995); and with primer set mmoXA$m m o X \mathrm{~B}$ developed for $m m o X$ genes by Auman et al. (2000) according to the previously described protocols. The PCR products were gel-purified using the Wizard PCR-Prep kit (Promega). Sequencing was performed using a Big Dye Terminator v.3.1 sequencing reaction kit and a DNA automatic sequencer (ABI 3730; Applied Biosystems). The sequences obtained in this study were first compared with those from GenBank using the BLAST algorithm (http://www. ncbi.nlm.nih.gov/BLAST; Altschul et al., 1997). The nucleotide and inferred amino acid sequences were aligned with similar sequences retrieved from the GenBank using CLUSTAL w [online software at the EBI (http://www.ebi.ac.uk; Larkin et al., 2007)]. The phylogenetic tree was constructed using the neighbour-joining algorithm using TREECONW (Van de Peer \& De Wachter, 1994).

Two types of colonies developed from the methanotrophic enrichments of Sphagnum peat tundra wetland samples collected from the Vorkuta region on the 2A agar medium with methane as the sole electron donor and carbon source after 4 weeks of incubation at $10{ }^{\circ} \mathrm{C}$. One of the colony types was circular, non-mucoid, opaque/creamy-coloured and 1$3 \mathrm{~mm}$ in diameter. The second type of colony was more convex, mucoid, dense, pale and $0.5-0.7 \mathrm{~mm}$ in diameter. Observations of the cells from the first colony type by phasecontrast microscopy showed that they were morphologically similar to those previously isolated from Vorkuta tundra soil and belonging to the genus Methylocella (Dedysh et al., 2004). The second type of colony contained big, rod-shaped cells with bipolar flagella. The colonies with the latter morphotype were obtained on $2 \mathrm{~A}$ agar medium with methanotrophic enrichments from the Chukotka and Yugorsky Peninsulas. The colonies formed by the bipolarflagellated cells were transferred to solid and liquid 2A media with methane and methanol as substrates. Three strains (V$022^{\mathrm{T}}$, Ch-022 and Yu-022) were selected, each representing one of the three methanotrophic enrichments used for isolation. In the media with methane, the new isolates could only grow for three consecutive inoculation/cultivation rounds, in contrast to those grown with media containing methanol, which exhibited stable growth. The purity of these cultures was confirmed by microscopy. Cells of these three strains were Gram-negative (as confirmed by microscopy), long, bipolar rods (Fig. 1a). The cells were $0.5-0.6 \mu \mathrm{m}$ wide and $1.3-4.5 \mu \mathrm{m}$ long. They reproduced through an irregular division which resulted in a short phase with motile cellular forms. Young cultures thus contained a large number of motile short rods with a subpolar flagellum (Fig. 1b). Forked cells were observed occasionally. An accumulation of mucous material was observed at one of the cellular poles, which may possibly mediate the cell-to-surface attachment and formation of forks (Fig. 1a, c). Old cultures contained larger numbers of forked cells.
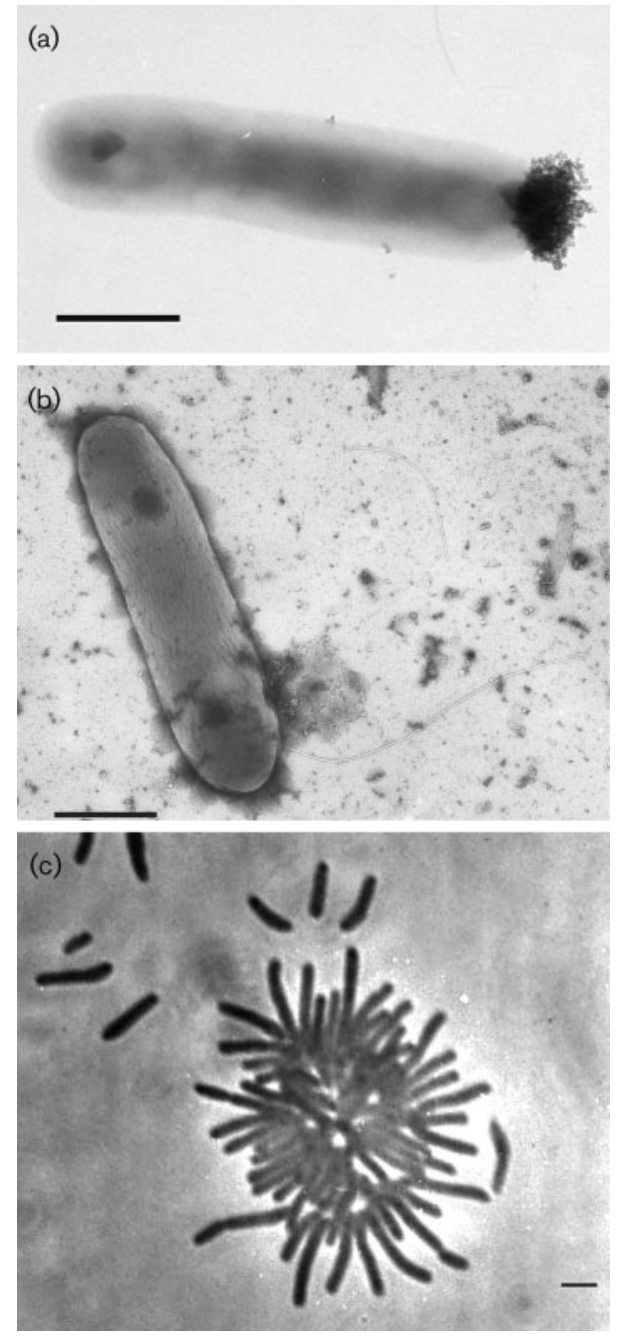

Fig. 1. Morphology of Methylorosula polaris sp. nov. (a) Mucous material at one of the cellular poles; (b) young cell with subpolar flagellum; (c), phase-contrast photomicrograph illustrating the formation of rosettes. Bars, $0.5 \mu \mathrm{m}$ ( $a$ and b), $1 \mu \mathrm{m}$ (c). Parts (a) and (b) were negatively stained with uranyl acetate.

Cultures grown in liquid media tended to flocculate upon achievement of later growth phases.

Microscopic analysis of the thin sections of cells grown on methanol revealed a Gram-negative cell wall type (Fig. 2). A larger periplasmic space was typically observed in young cells.

A variety of carbon compounds were tested for their ability to support the growth of the isolates (Table 1). The isolates were able to use a broad spectrum of organic compounds, including $\mathrm{C}_{1}$-compounds, mono-, di- and trisaccharides, polysaccharides, sugar, alcohols, amino acids and Casamino acids. Certain differences were observed in the utilization pattern of various compounds by the three isolates. In contrast to strain $\mathrm{V}-022^{\mathrm{T}}$, strain $\mathrm{Ch}-022$ did not utilize raffinose, glycerol or L-phenylalanine, but was able to utilize 


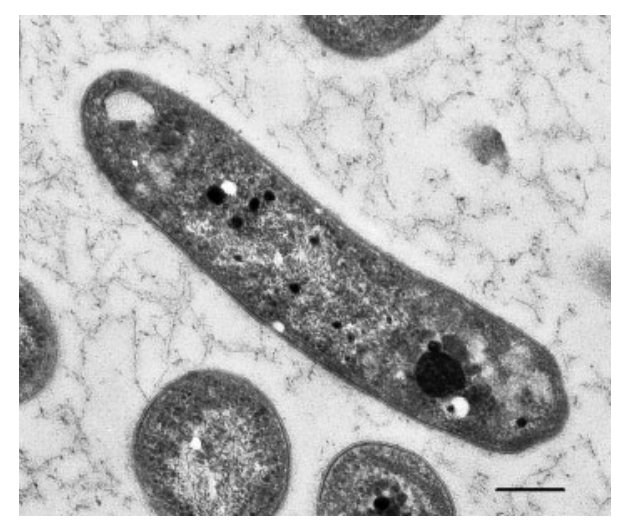

Fig. 2. Ultrastructure of Methylorosula polaris sp. nov. Bar, $0.5 \mu \mathrm{m}$.

cysteine. Strain Yu-022, unlike the other isolates, did not utilize trehalose, inosine, ethanol or isoleucine. None of the strains utilized butanol, pectin, amino acids (histidine and methionine) or salts of organic acids (pyruvate, lactate, succinate, malate, formate, acetate, propionate and butyrate) and were not autotrophic with hydrogen as the electron donor. Thus the isolates were heterotrophic bacteria that, in addition to $\mathrm{C}_{1}$-compounds, were able to utilize a broad variety of organic compounds including methylated ones. The strains were able to use ammonium, nitrate and yeast extract as nitrogen sources. The three novel strains were unable to fix atmospheric nitrogen under the conditions tested in nitrogen-free media.

Table 1. Comparative characteristics of strains $\mathrm{V}-022^{\top}$, Ch-022 and Ju-022

All strains were able to grow with methanol, methylamines (mono-, di-, tri-), monosaccharides, disaccharides maltose, lactose and sucrose, polysaccharides starch and dextrin, sugar alcohols, dulcitol, sorbitol and mannitol, amino acids alanine, glutamine, arginine and proline; yeast extract and Casamino acids. None of the strains were able to grow with butanol, with amino acids histidine or methionine, or with salts of organic acids.

\begin{tabular}{|lccc|}
\hline Characteristic & $\mathbf{V - 0 2 2}^{\mathbf{T}}$ & $\mathbf{C h - 0 2 2}$ & $\mathbf{J u - 0 2 2}$ \\
\hline Growth on: & & & \\
Trehalose & + & + & - \\
Raffinose & + & - & + \\
Glycerol & + & - & + \\
Inosine & + & + & - \\
Ethanol & + & + & - \\
Isoleucine & + & + & - \\
Phenylalanine & + & - & + \\
Cysteine & - & + & - \\
Serine & - & - & + \\
DNA G+C content (mol\%) & 65.2 & 64.0 & 65.0 \\
& & & \\
\hline
\end{tabular}

Table 2. Cellular fatty acid compositions of strain $\mathrm{V}-022^{\top}$, Methylocella tundrae and Methylocapsa acidiphila of the family Beijerinckiaceae

Taxa: 1, V-022 ${ }^{\mathrm{T}} ; 2$, Methylocella tundrae $\mathrm{T}^{\mathrm{T}}$ (Data from Dedysh et al., 2004); 3, Methylocapsa acidiphila B2 ${ }^{\mathrm{T}}$ (Dedysh et al., 2002). ND, not detected.

\begin{tabular}{|lccc|}
\hline Fatty acid & $\mathbf{1}$ & $\mathbf{2}$ & $\mathbf{3}$ \\
\hline $\mathrm{C}_{14: 0}$ & $\mathrm{ND}$ & $2.6-4.1$ & $\mathrm{ND}$ \\
$\mathrm{C}_{15: 0}$ & $\mathrm{ND}$ & $\mathrm{ND}$ & $\mathrm{ND}$ \\
$\mathrm{C}_{16: 0}$ iso & 0.7 & $\mathrm{ND}$ & $\mathrm{ND}$ \\
$\mathrm{C}_{16: 1} \omega 7 c$ & 3.6 & $7.2-11.3$ & 4.7 \\
$\mathrm{C}_{16: 1} \omega 5 c$ & 6.8 & $\mathrm{ND}$ & 0.1 \\
$\mathrm{C}_{16: 0}$ & 6.5 & $7.2-7.7$ & 7.3 \\
$\mathrm{C}_{17: 0}$ iso & 0.5 & $0.4-0.6$ & 0.6 \\
$\mathrm{C}_{17: 1} \omega 8 c$ & $\mathrm{ND}$ & $0-0.3$ & $\mathrm{ND}$ \\
$\mathrm{C}_{17: 1} \omega 7 c$ & $\mathrm{ND}$ & $\mathrm{ND}$ & 1.0 \\
$\mathrm{C}_{17: 1} \omega 6 c$ & $\mathrm{ND}$ & $0-0.1$ & $\mathrm{ND}$ \\
$\mathrm{C}_{17: 0}$ cyclo & 1.7 & $5.0-6.5$ & $\mathrm{ND}$ \\
$\mathrm{C}_{18: 0}$ iso & 0.3 & $\mathrm{ND}$ & $\mathrm{ND}$ \\
$\mathrm{C}_{18: 1} \omega 7 c$ & 66.8 & $59.2-61.7$ & 78.3 \\
$\mathrm{C}_{18: 0}$ & 1.7 & $0.4-0.6$ & 7.6 \\
$\mathrm{C}_{19: 0} \omega 8 c$ cyclo & 11.1 & $7.9-13.6$ & $\mathrm{ND}$ \\
$\mathrm{C}_{19: 0}$ & 0.4 & $\mathrm{ND}$ & $\mathrm{ND}$ \\
\hline
\end{tabular}

The isolates were moderately acidophilic organisms showing growth at $\mathrm{pH}$ 4.0-7.8 (optimum at pH 5.5-6.0) (Table 1). The strains were psychrotolerant with a temperature range for growth of $4-30{ }^{\circ} \mathrm{C}$ (optimum, $20-25{ }^{\circ} \mathrm{C}$ ). No growth occurred at $37^{\circ} \mathrm{C}$. The culture generation time with methanol $(0.1 \%, \mathrm{v} / \mathrm{v})$ calculated from increases in $\mathrm{OD}_{600}$ at the exponential phase (over a total of 7 days) was 25$36 \mathrm{~h}$. No growth inhibition was observed in the presence of $\mathrm{NaCl}$ in the medium at concentrations of $0.1-0.5 \%(\mathrm{w} / \mathrm{v})$. Growth rates were inhibited by $50 \%$ at concentrations of $1-$ $1.5 \% \mathrm{NaCl}(\mathrm{w} / \mathrm{v})$, whereas concentrations above $2.0 \%$ completely inhibited growth.

Table 2 shows the fatty acid composition of strain $\mathrm{V}-22^{\mathrm{T}}$. The fatty acids comprised mainly straight-chain saturated

Table 3. Enzyme activities in cell extracts of strain $\mathrm{V}-022^{\top}$ grown with methylamine

The activities are expressed as nmol $\mathrm{min}^{-1} \mathrm{mg}^{-1}$ of protein.

\begin{tabular}{|llc|}
\hline Enzyme & Cofactor & $\begin{array}{r}\text { Enzyme } \\
\text { activity }\end{array}$ \\
\hline Methylamine dehydrogenase & $\mathrm{PMS}$ & 90 \\
Formaldehyde dehydrogenase & $\mathrm{NAD}^{+}$ & 2 \\
& $\mathrm{NAD}^{+}, \mathrm{GSH}$ & 520 \\
Formate dehydrogenase & $\mathrm{NAD}^{+}$ & 140 \\
Hydroxypyruvate reductase & $\mathrm{NADH}$ & - \\
& $\mathrm{NADPH}$ & - \\
3-Hexulose phosphate synthase & & - \\
Ribulose-1,5-bisphosphate carboxylase & & 10 \\
\hline
\end{tabular}


and unsaturated fatty acids together with a diagnostic amount of cyclopropane fatty acids showing 17 and 19 carbon atoms. The major component of the phospholipid fatty acid (PLFA) profiles of the novel isolates was 11-cisoctadecenoic acid $\left(\mathrm{C}_{18: 1} \omega 7 \mathrm{c}\right)$, which comprised $66.78 \%$ of the total PLFAs. This composition was similar to that found previously for Methylocella tundrae and Methylocapsa acidiphila. The fatty acid pattern of the novel organisms was most similar to that found in the type strain of Methylocella tundrae (Dedysh et al., 2004). The distinctive feature of the
PLFA profiles of the novel methylotrophs was the presence of $\mathrm{C}_{16: 1} \omega 5 c$ fatty acids and small amounts of iso-branched fatty acids $\left(\mathrm{C}_{16: 0}\right.$ iso and $\mathrm{C}_{18: 0}$ iso $)$. The DNA G $+\mathrm{C}$ content of strain $\mathrm{V}-022^{\mathrm{T}}$ was $65.2 \mathrm{~mol} \%$.

Measurements of the activities of key enzymes of $\mathrm{C}_{1}$ metabolism of the methylamine-grown cells indicated the presence of methylamine dehydrogenase activity (Table 3 ). Formaldehyde was further oxidized by GSH-dependent formaldehyde dehydrogenase to formate. The latter was

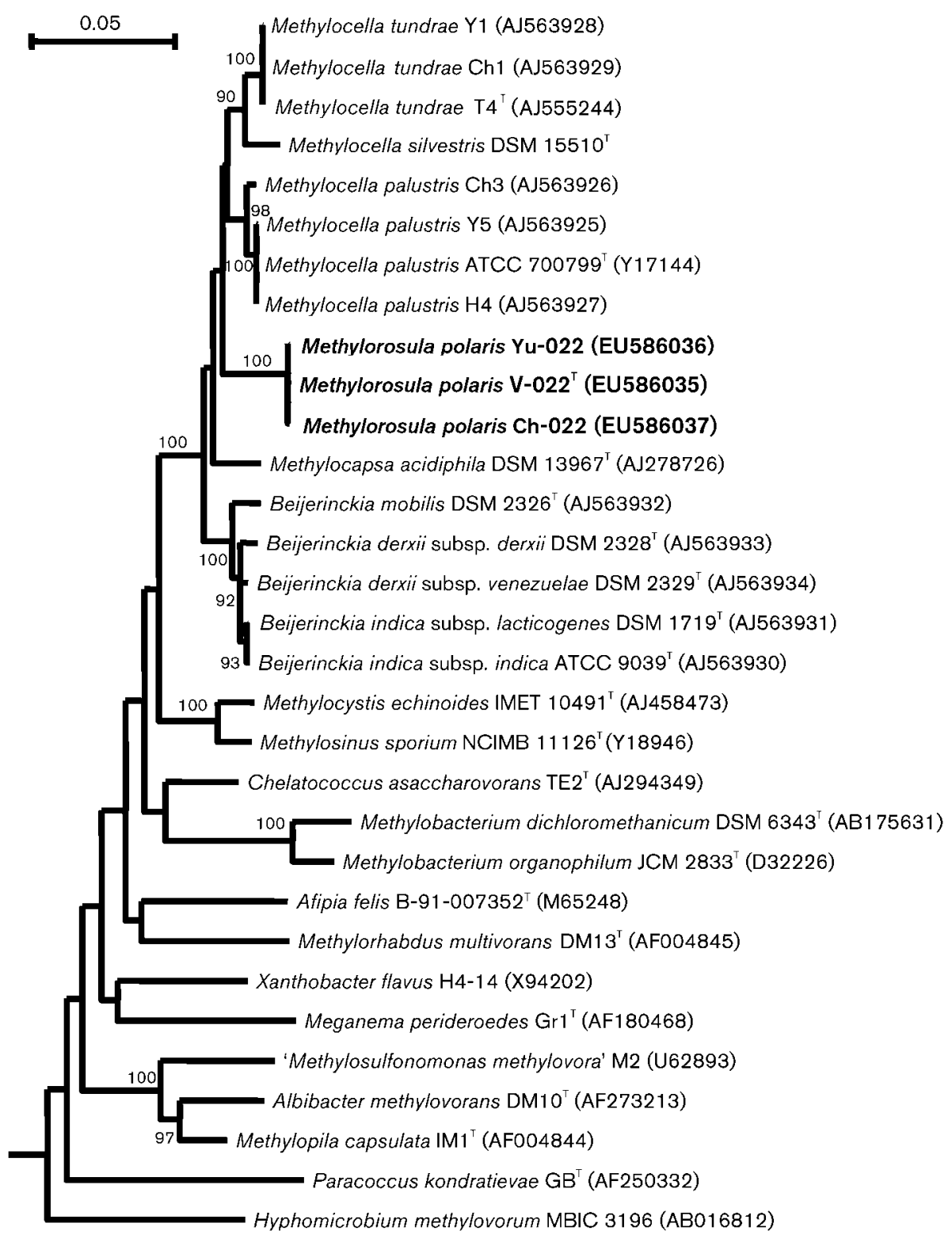

Fig. 3. $16 \mathrm{~S}$ rRNA gene sequence-based dendrogram showing the phylogenetic position of strains $\mathrm{V}-022^{\top}, \mathrm{Ch}-022$ and $\mathrm{Yu}-$ 022 in relation to representative members of the class Alphaproteobacteria. Evolutionary distances were calculated by the method of Jukes \& Cantor (1969). The root was determined by using the 16S rRNA gene sequence of Methylococcus capsulatus ATCC $19069^{\top}$ (GenBank accession no. X72770) as the outgroup. The numbers at the nodes are bootstrap values as derived from 1000 data resamplings; values $>75$ were considered as significant. Bar, 0.05 substitutions per nucleotide position. 
(a)

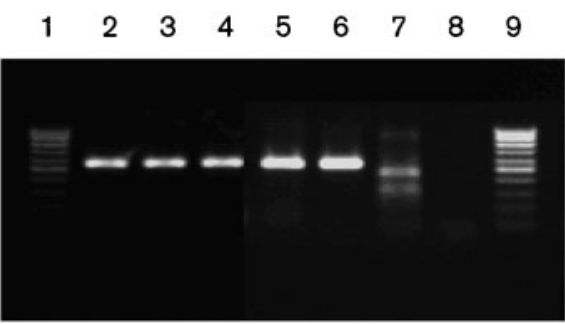

(b)

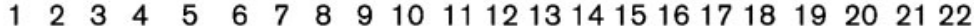

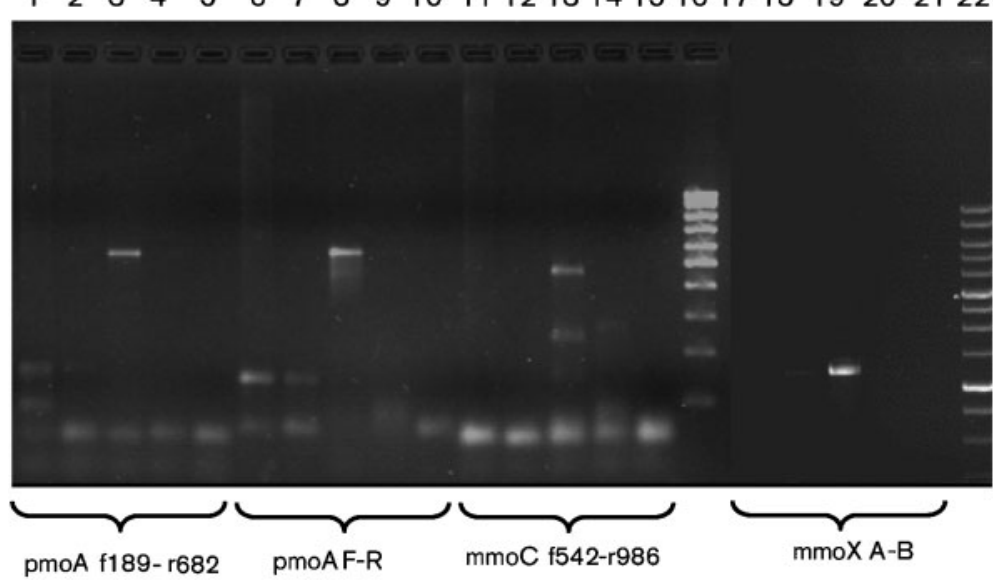

Fig. 4. $P C R$ analysis for determination of functional genes of the novel methylotrophic strains. (a) $m x a F$ gene. Lanes: 1, $0.1 \mathrm{~kb}$ marker (Sibenzyme, Russia); 2, V-022 ${ }^{\top} ; 3$, Ch-022; 4, Yu-022; 5, Methylocella tundrae $\mathrm{T} 4^{\top}$ (positive control); 6, Methylosinus sporium NCIMB $11126^{\top}$ (positive control); 7, Escherichia coli (negative control); 8, control without DNA; 9 , $0.1 \mathrm{~kb}$ marker (Sibenzyme, Russia). (b) $M M O$ genes. Lanes: 1, 6, 11 and 17, strain $\mathrm{V}-022^{\top}$; 2, 7, 12 and 18, strain Yu-022; 3, 8, 13 and 19 , Methylocella tundrae $\mathrm{T}^{\top}{ }^{\top}$ (positive control); 4, 9, 14 and 20, Escherichia coli (negative control); 5, 10, 15 and 21, control without DNA; 16 and 22, $0.1 \mathrm{~kb}$ marker (Sibenzyme, Russia). finally oxidized to $\mathrm{CO}_{2}$ by NAD-linked formate dehydrogenase. Carbon dioxide was assimilated via the RuBP pathway (Benson-Calvin cycle), as confirmed by the presence of ribulose-1,5-bisphosphate carboxylase. Neither the serine nor the ribulose monophosphate pathway of $\mathrm{C} 1$ assimilation was operative, due to the absence of the appropriate specific enzymes: hydroxypyruvate reductase and hexulose phosphate synthase.

Comparative sequence analysis of the $16 \mathrm{~S}$ rRNA gene fragments (almost $1400 \mathrm{nt}$ ) revealed that strains $\mathrm{V}-022^{\mathrm{T}}$, Ch-022 and Yu-022 possessed almost identical 16S rRNA gene sequences (99.9\% sequence similarity). The 16S rRNA gene-based phylogenetic analyses demonstrated that the isolates belonged to the family Beijerinckiaceae in the class Alphaproteobacteria and represented a novel independent lineage with $97.0 \%$ sequence similarity to the nearest relative (Fig. 3). Since the new isolates formed a separate lineage with uncertain branching among other members of the family Beijerinckiaceae, key functional genes, such as $m x a F$ (methanol dehydrogenase) and pMMO and sMMO (methane monooxygenase) were also analysed. The mxaF gene was easily detectable in the novel isolates (Fig. 4a), but all attempts to amplify $p M M O$ or $s M M O$ genes, using different primer sets, failed (Fig. 4b). Phylogenetic analysis of translated amino acid sequences (162 aa) of the mxaF gene fragments (486 nt) from strains $\mathrm{V}-022^{\mathrm{T}}$ and $\mathrm{Yu}-022$ confirmed the 16S rRNA gene-based data. This placed the novel isolates amongst the methylotrophic alphaproteobacteria as a separate branch, which confirmed their unusual position among known methylotrophs (Fig. 5).

In this study, three strains of a new facultatively methylotrophic bacterium were isolated that belong to the class Alphaproteobacteria and form a separate monophyletic lineage within the family Beijerinckiaceae. These new organisms are phenotypically distinct from the other known representatives of the family (Table 4). These novel methylotrophic organisms reproduce by irregular division, are motile by means of a subpolar flagellum and do not produce dormant forms. The isolates do not fix atmospheric nitrogen as found for some other members of the family Beijerinckiaceae. In comparison with the methanotrophic representatives of the family Beijerinckiaceae from the genera Methylocella and Methylocapsa, cells of the novel strains do not utilize methane as a source of carbon and energy and use the RuBP pathway for the assimilation of one-carbon compounds. In contrast to the members of the genera Beijerinckia and Methylocella, the new isolates do not utilize organic acids, but are able to use methylated amines and amino acids. The $\mathrm{G}+\mathrm{C}$ content in the DNA of the novel organisms was higher than that previously found for the other representatives of the family Beijerinckiaceae.

On the basis of a polyphasic analysis of their phenotypic and genotypic properties, the novel strains of acid-tolerant, facultative methylotrophic alphaproteobacteria from three 


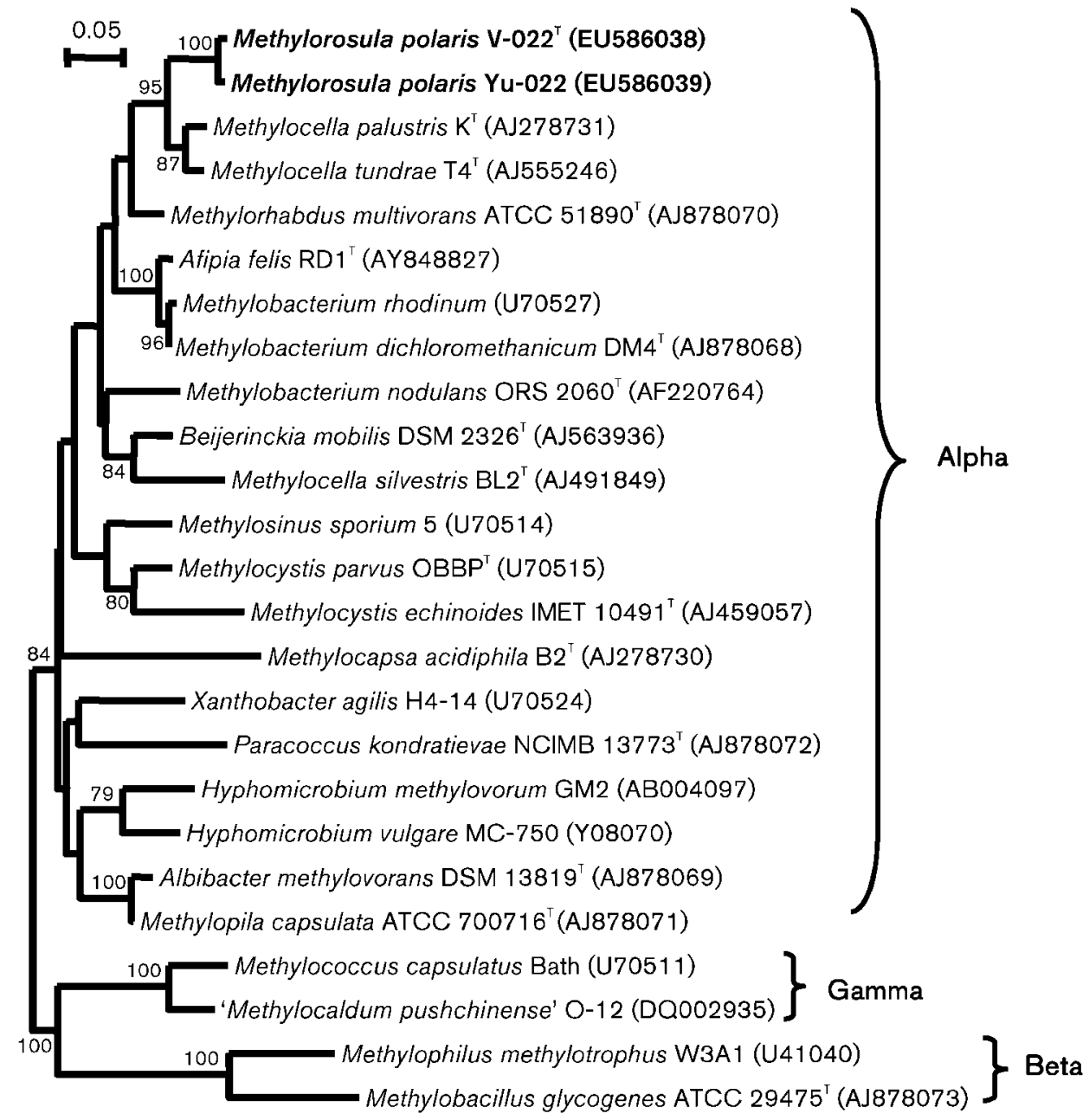

Fig. 5. Unrooted phylogenetic tree of methylotrophic members of the class Proteobacteria based on comparative analysis of conceptual translations of $m x a F$ genes. Bar, $5 \%$ sequence variation. Bootstrap values $>75 \%$ (based on 1000 data resamplings) are indicated at the nodes.

different tundra wetland sites are proposed as representing a new genus and novel species, for which the name Methylorosula polaris gen. nov., sp. nov. is proposed. The type strain is strain $\mathrm{V}-022^{\mathrm{T}}\left(=\mathrm{DSM} 22001^{\mathrm{T}}=\mathrm{VKM} \mathrm{V}-\right.$ $\left.2485^{\mathrm{T}}\right)$.

\section{Description of Methylorosula gen. nov.}

Methylorosula [Me.thyl.o.ro'su.la. N.Gr. n. methyl (from Gr. n. methu wine and Gr. n. hulê wood); L. fem. n. rosula a little rose; N.L. fem. n. Methylorosula methyl-using forming rosette cells].

Cells are Gram-negative rods that are not capable of nitrogen fixation. Aerobic, facultative methylotrophic bacteria. Chemoorganoheterotrophic. Use the RuBP pathway (Benson-Calvin cycle) for carbon assimilation. The dominant cellular fatty acid is $\mathrm{C}_{18: 1} \omega 7 \mathrm{c}$. A member of the family Beijerinckiaceae in the class Alphaproteobacteria. Methylorosula polaris is the type species of the genus.

\section{Description of Methylorosula polaris sp. nov.}

Methylorosula polaris (po.la'ris. N.L. fem. adj. polaris pertaining to the geographical zone in Northern Russia, where the type strain was isolated).

Displays the following properties in addition to those described for the genus. Cells are long, bipolar rods (0.5$0.6 \times 1.3-4.5 \mu \mathrm{m})$ that are single or form rosettes. Reproduces by irregular fission. Young cells are motile by means of a subpolar flagellum. Forms pale, non-translucent slimy (mucoid) colonies with an uneven edge. After 2 weeks of growth on methanol at $20{ }^{\circ} \mathrm{C}$, colonies are $1.5-2.0 \mathrm{~mm}$ in size. Utilizes $\mathrm{C}_{1}$-compounds, methanol and methylamines, sugars, polysaccharides, sugar alcohols and amino acids as a carbon and energy source. The temperature and $\mathrm{pH}$ ranges for growth are $4-30{ }^{\circ} \mathrm{C}$ (optimum, $20-25{ }^{\circ} \mathrm{C}$ ) and $\mathrm{pH}$ 4.0-7.8 (optimum, pH 5.5-6.0), respectively. $\mathrm{NaCl}$ is not required for growth and is tolerated up to a concentration of $2.0 \%(\mathrm{w} / \mathrm{v})$. The major fatty acid is $\mathrm{C}_{18: 1} \omega 7 c$. 
Table 4. Major characteristics that distinguish Methylorosula gen. nov. from other genera of the family Beijerinckiaceae

Taxa: 1, Methylorosula gen. nov.; 2, Methylocella (data from Kennedy, 2005; Dedysh et al., 2005a); 3, Beijerinckia (Kennedy, 2005); 4, Methylocapsa (data from Dedysh et al., 2002).

\begin{tabular}{|c|c|c|c|c|}
\hline Characteristic & 1 & 2 & 3 & 4 \\
\hline Size $(\mu \mathrm{m})$ & $0.5-0.6 \times 1.3-4.5$ & $0.6-1.0 \times 1.0-2.5$ & $0.5-1.5 \times 7-4.5$ & $0.7-1.0 \times 0.8-1.2$ \\
\hline Division & Irregular & Regular & Regular & Regular \\
\hline Rosette formation & + & - & - & - \\
\hline Type of resting cells & - & Exospores & Cysts, capsules & Azotobacter-type cysts \\
\hline $\mathrm{CH}_{4}$ & - & + & - & + \\
\hline Methanol & + & + & $+1-$ & $\leqslant 0.05 \%$ \\
\hline Methylamines & + & - & - & - \\
\hline Sugars & + & - & + & - \\
\hline Ethanol & + & + & - & - \\
\hline Amino acids & + & - & - & - \\
\hline
\end{tabular}

The type strain, $\mathrm{V}-022^{\mathrm{T}}\left(=\mathrm{DSM} 22001^{\mathrm{T}}=\mathrm{VKM} \mathrm{V}-2485^{\mathrm{T}}\right)$, was isolated from tundra wetland soil. The DNA G+C content of the type strain is $65.2 \mathrm{~mol} \%$.

\section{Acknowledgements}

This research was supported by the Federal Scientific Programs of the Presidium of the Russian Academy of Sciences no. 16 and 'The Biodiversity'. The authors thank Dr A. M. Lysenko for analysis of $\mathrm{G}+\mathrm{C}$ content in the DNA of the isolated strains.

\section{References}

Altschul, S. F., Madden, T. L., Schäffer, A. A., Zhang, J., Zhang, Z., Miller, W. \& Lipman, D. J. (1997). Gapped BLAST and PSI-BLAST: a new generation of protein database search programs. Nucleic Acids Res 25, 3389-3402.

Anthony, C. (1982). The Biochemistry of Methylotrophs. New York: Academic Press.

Auman, A. J., Stolyar, S., Costello, A. M. \& Lidstrom, M. E. (2000). Molecular characterization of methanotrophic isolates from freshwater lake sediment. Appl Environ Microbiol 66, 5259-5266.

Berestovskaya, Yu. Yu., Vasilyeva, L. V., Chestnykh, O. V. \& Zavarzin, G. A. (2002). Methanotrophs of the psychrophilic microbial community of Russian arctic tundra. Microbiology (English translation of Mikrobiologiia) 71, 538-544.

Bodrossy, L., Holmes, E. M., Holmes, A. J., Kovács, K. L. \& Murrell, J. C. (1997). Analysis of $16 \mathrm{~S}$ rRNA and methane monooxygenase gene sequences reveals a novel group of thermotolerant and thermophilic methanotrophs, Methylocaldum gen. nov. Arch Microbiol 168, 493503.

Bowman, J. P., McCammon, S. A. \& Skerratt, J. H. (1997). Methylosphaera hansonii gen. nov., sp. nov., a psychrophilic, group I methanotroph from Antarctic marine-salinity, meromictic lakes. Microbiology 143, 1451-1459.
De Ley, J., Cattoir, H. \& Reynaerts, A. (1970). The quantitative measurement of DNA hybridization from renaturation rates. Eur $J$ Biochem 12, 133-142.

Dedysh, S. N., Khmelenina, V. N., Suzina, N. E., Trotsenko, Y. A., Semrau, J. D., Liesack, W. \& Tiedje, J. M. (2002). Methylocapsa acidiphila gen. nov., sp. nov., a novel methane-oxidizing and dinitrogen-fixing acidophilic bacterium from Sphagnum bog. Int $J$ Syst Evol Microbiol 52, 251-261.

Dedysh, S. N., Berestovskaya, Y. Y., Vasylieva, L. V., Belova, S. E., Khmelenina, V. N., Suzina, N. E., Trotsenko, Y. A., Liesack, W. \& Zavarzin, G. A. (2004). Methylocella tundrae sp. nov., a novel methanotrophic bacterium from acidic tundra peatlands. Int J Syst Evol Microbiol 54, 151-156.

Dedysh, S. N., Knief, C. \& Dunfield, P. F. (2005a). Methylocella species are facultatively methanotrophic. J Bacteriol 187, 4665-4670.

Dedysh, S. N., Smirnova, K. V., Khmelenina, V. N., Suzina, N. E., Liesack, W. \& Trotsenko, Y. A. (2005b). Methylotrophic autotrophy in Beijerinckia mobilis. J Bacteriol 187, 3884-3888.

Doronina, N. V., Trotsenko, Y. A., Krausova, V. I., Boulygina, E. S. \& Tourova, T. P. (1998). Methylopila capsulata gen. nov., sp. nov., a novel non-pigmented aerobic facultatively methylotrophic bacterium. Int J Syst Bacteriol 48, 1313-1321.

Eady, R. R. \& Large, P. J. (1968). Purification and properties of an amine dehydrogenase from Pseudomonas AM1 and its role in growth on methylamine. Biochem J 106, 245-255.

Holmes, A. J., Costello, A., Lidstrom, M. E. \& Murrell, J. C. (1995). Evidence that particulate methane monooxygenase and ammonia monooxygenase may be evolutionarily related. FEMS Microbiol Lett 132, 203-208.

Jukes, T. H. \& Cantor, C. R. (1969). Evolution of protein molecules. In Mammalian Protein Metabolism, vol. 3, pp. 21-132. Edited by H. N. Munro. New York: Academic Press.

Kennedy, C. (2005). Genus I. Beijerinckia. In Bergey's Manual of Systematic Bacteriology, 2nd edn, vol. 2C, pp. 423-432. Edited by D. J. Brenner, N. R. Krieg, J. T. Staley \& G. M. Garrity. New York: Springer. 
Larkin, M. A., Blackshields, G., Brown, N. P., Chenna, R., McGettigan, P. A., McWilliam, H., Valentin, F., Wallace, I. M., Wilm, A. \& other authors (2007). CLUSTAL W and CLUSTAL X version 2.0. Bioinformatics 23, 2947-2948.

Lidstrom, M. E. (2006). Aerobic methylotrophic prokaryotes. In The Prokaryotes, 3rd edn, vol. 2, pp. 618-634. Edited by M. Dworkin, S. Falkow, E. Rosenberg, K. H. Schleifer \& E. Stackebrandt. New York: Springer.

Loginova, N. V. \& Trotsenko, Y. A. (1979). Autotrophic growth on methanol by bacteria isolated from activated sludge. FEMS Microbiol Lett 5, 239-243.

Lowry, O. H., Rosebrough, N. J., Farr, A. L. \& Randall, R. J. (1951). Protein measurement with the Folin phenol reagent. J Biol Chem 193, 265-275.

MacDonald, R. C. \& Fall, R. (1993). Detection of substantial emissions of methanol from plants to the atmosphere. Atmos Environ 27, 1709-1713.

Marmur, J. (1961). A procedure for the isolation of deoxyribonucleic acid from micro-organisms. J Mol Biol 3, 208-214.

McDonald, I. R. \& Murrell, J. C. (1997). The methanol dehydrogenase structural gene mxaF and its use as a functional gene probe for methanotrophs and methylotrophs. Appl Environ Microbiol 63, 32183224.

McDonald, I. R., Kenna, E. M. \& Murrell, J. C. (1995). Detection of methanotrophic bacteria in environmental samples with the PCR. Appl Environ Microbiol 61, 116-121.
Senum, G. I. \& Gaffney, J. S. (1985). A reexamination of the tropospheric methane cycle: geophysical implications. In The Carbon Cycle and Atmospheric $\mathrm{CO}_{2}$ : Natural Variations, Archean to Present, pp. 61-69. Edited by E. T. Sundquist \& W. S. Broecker. Washington, DC: American Geophysical Union.

Sorokin, D. Yu., Trotsenko, Y. A., Doronina, N. V., Tourova, T. P., Galinski, E. A., Kolganova, T. V. \& Muyzer, G. (2007). Methylohalomonas lacus gen. nov., sp. nov. and Methylonatrum kenyense gen. nov., sp. nov., methylotrophic gammaproteobacteria from hypersaline lakes. Int J Syst Evol Microbiol 57, 2762-2769.

Trotsenko, Y. A. \& Khmelenina, V. N. (2002). Biology of extremophilic and extremotolerant methanotrophs. Arch Microbiol 177, 123131.

Trotsenko, Yu. A., Ivanova, E. G. \& Doronina, N. V. (2001). Aerobic methylotrophic bacteria as phytosymbionts. Microbiology (English translation of Mikrobiologiia) 70, 623-633.

Van de Peer, Y. \& De Wachter, R. (1994). TREECON for Windows: a software package for the construction and drawing of evolutionary trees for the Microsoft Windows environment. Comput Appl Biosci 10, 569-570.

Vasilyeva, L. V., Omelchenko, M. V., Berestovskaya, Y. Y., Lysenko, A. M., Abraham, W.-R., Dedysh, S. N. \& Zavarzin, G. A. (2006). Asticcacaulis benevestitus sp. nov., a psychrotolerant, dimorphic, prosthecate bacterium from tundra wetland soil. Int J Syst Evol Microbiol 56, 2083-2088. 